\title{
The journey of gastric phytobezoar followed by tomography
}

\author{
Deniz Çebi Olgun, M.D., ${ }^{1}$ Yasemin Kayadibi, M.D., ${ }^{1}$ \\ Osman Şimşek, M.D., ${ }^{2}$ Zekeriya Karaduman, M.D. ${ }^{2}$
}

1Department of Radiology, İstanbul University Cerrahpaşa Faculty of Medicine, Istanbul;
${ }^{2}$ Department of General Surgery, İstanbul University Cerrahpaşa Faculty of Medicine, İstanbul

\begin{abstract}
Phytobezoars are a rare cause of intestinal obstruction. They are usually present in patients with predisposing factors such as previous gastric surgery, diabetes, and edentulousness. In this case report, an uncommon cause of intestinal obstruction due to the migration of gastric phytobezoar in a patient with no known predisposing factor is reported.
\end{abstract}

Key words: Intestinal obstruction; migration; persimmon; phytobezoar.

\section{INTRODUCTION}

Pyhtobezoars are the most common type of bezoars in adults. Diospyrobezoars formed after massive ingestion of persimmons are a special subtype of phytobezoars that can be endemic in some countries. ${ }^{[1-3]}$ They are usually found in the stomach and rarely cause intestinal obstruction. Diagnosis is always made by a combination of patient history, clinical and radiological findings. In this combination, radiologic findings are very important since computer tomography $(\mathrm{CT})$ could be a problem solver with characteristic findings for bezoars. ${ }^{[3]}$ In the presented case, it is aimed to discuss the imaging features of the journey of a gastric bezoar.

\section{CASE REPORT}

A 53-year-old woman was admitted to our emergency department with vomiting, constipation, abdominal pain, and distension of a few hours. She had an additional medical history of gastric bezoar diagnosed by CT performed in advance for abdominal pain and confirmed by endoscopy a week ago (Fig. Ia, b). She confirmed no surgical interven-

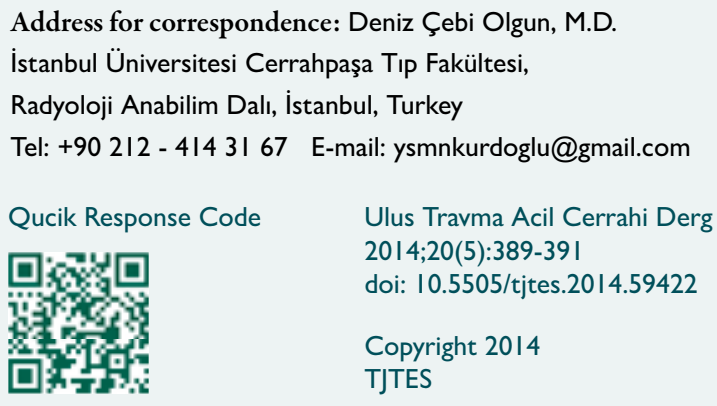

tions were conducted beforehand. On physical examination, bowel sounds were hyperactive and there was no palpable mass in the rectum. Plain X-ray graph of abdomen showed multiple air-fluid levels with no free air under diaphragm. Her complete blood count and biochemical profile were in normal limits. CT of the abdomen revealed dilated jejunal and ileal intestinal loops reaching up to $4-5 \mathrm{~cm}$ and a welldefined intraluminal mass within mottled gas pattern at the point of transitional zone (Fig. Ic, d). Under the transitional zone, distal ileal loops were collapsed. With the history of gastric bezoar and imaging findings, patient was diagnosed as intestinal obstruction due to migration of the gastric bezoar. Under general anesthesia, patient underwent laparoscopic exploration. Intra-surgical findings were dilated edematous ileal loops extending $150 \mathrm{~cm}$ from ileocaecal junction and intraluminal mass causing obstruction at the level of transition zone. The incision of suprapubic trocar was enlarged, enterotomy performed ("mini-lap" technique), and suggested obstructing pathology of bezoar measuring $5 \mathrm{~cm}$ was removed (Fig. le, f). Postoperative period was uneventful and patient was discharged 5 days later.

\section{DISCUSSION}

Bezoars are compact forms of undigested material found in the gastrointestinal tract. There are many types of bezoars differing by material content including phytobezoars containing undigested vegetable or fruit, trichobezoars containing hair, lactobezoars containing milk and pharmacobezoars containing drugs such as cholestyramine, kayexalate, resin, cavafate, and antacids..$^{[1,2]}$

Diospyrobezoar, the most common subtype of phytobezoar, 
occur after excessive intake of the fruit, persimmon. In some countries like Japan and Israel, epidemics have been reported. Tannin found in the skin of persimmon reacts with the gastric fluid and reactants and play role in the nucleus formation of bezoars. ${ }^{[4]}$ Normally, pylorus does not allow undigested materials such as vegetable fibers to pass until soft enough. In patients with previous gastric surgery and vagotomy, gastric functions fail in digestion, facilitating bezoar formation. With patients of no history of gastric surgery, diabetic gastroparesis, vegetarian diet, hypothyroidism or edentulousness could be the other predisposing factors. ${ }^{[2-7]}$ Our patient had none of these factors. However, out patient's history revealed that there was an excessive consumption of persimmon.

Phytobezoars are usually diagnosed incidentally without giving any symptoms when in the stomach. They rarely pass to small bowel and cause intestinal obstruction consisting only 0.4 to $4 \%$ of total intestinal obstructions. Strictures or adhesions of the small bowel due to diseases such as Crohn's or tuberculosis or previous surgery are causes of primary intestinal bezoars. ${ }^{[2,3,6]}$ Terminal ileum is the most common site of obstruction followed by jejunum. Symptoms such as abdominal pain, vomiting or dyspepsia are the common presenting symptoms assisting in locating the bezoars. ${ }^{[2-7]}$
Radiologically, plain X-ray graphics are not diagnostic otherwise showing air-fluid levels. However, series of $\mathrm{X}$-ray graphics may be helpful in the follow-up of possible obstruction due to fragmented bezoars in treatment. CT has 73$93 \%$ success rate of diagnosis. ${ }^{[7]}$ In CT, gastric or intestinal, intraluminal, well-defined mass with mottled gas pattern is the characteristic imaging feature for bezoars. If this image is recognized at the point of transitional zone, bezoar as an obstructing factor may be suggested when a patient comes with ileus. Sometimes small bowel feces may mimic bezoars but generally feces are placed more proximal to the transitional zone and they usually appear as tubular structures not round like bezoars. ${ }^{[1,2,7]}$ These CT findings, combined with the history of primary gastric bezoar in our patient, were very helpful in diagnosis.

Surgery is the best modality of treatment, if obstruction occurs. However, in patients without obstruction, endoscopic therapy of fragmentation, treatment with enzymes such as papain and cellulose or chemical dissolution with pineapple juice or Coca-Cola are other treatment modalities described for bezoars. After treatment, recurrence is not expected, if there is no predisposing factor. ${ }^{[1,2,5]}$ On the other hand, if patients left untreated, apart from intestinal obstruction,
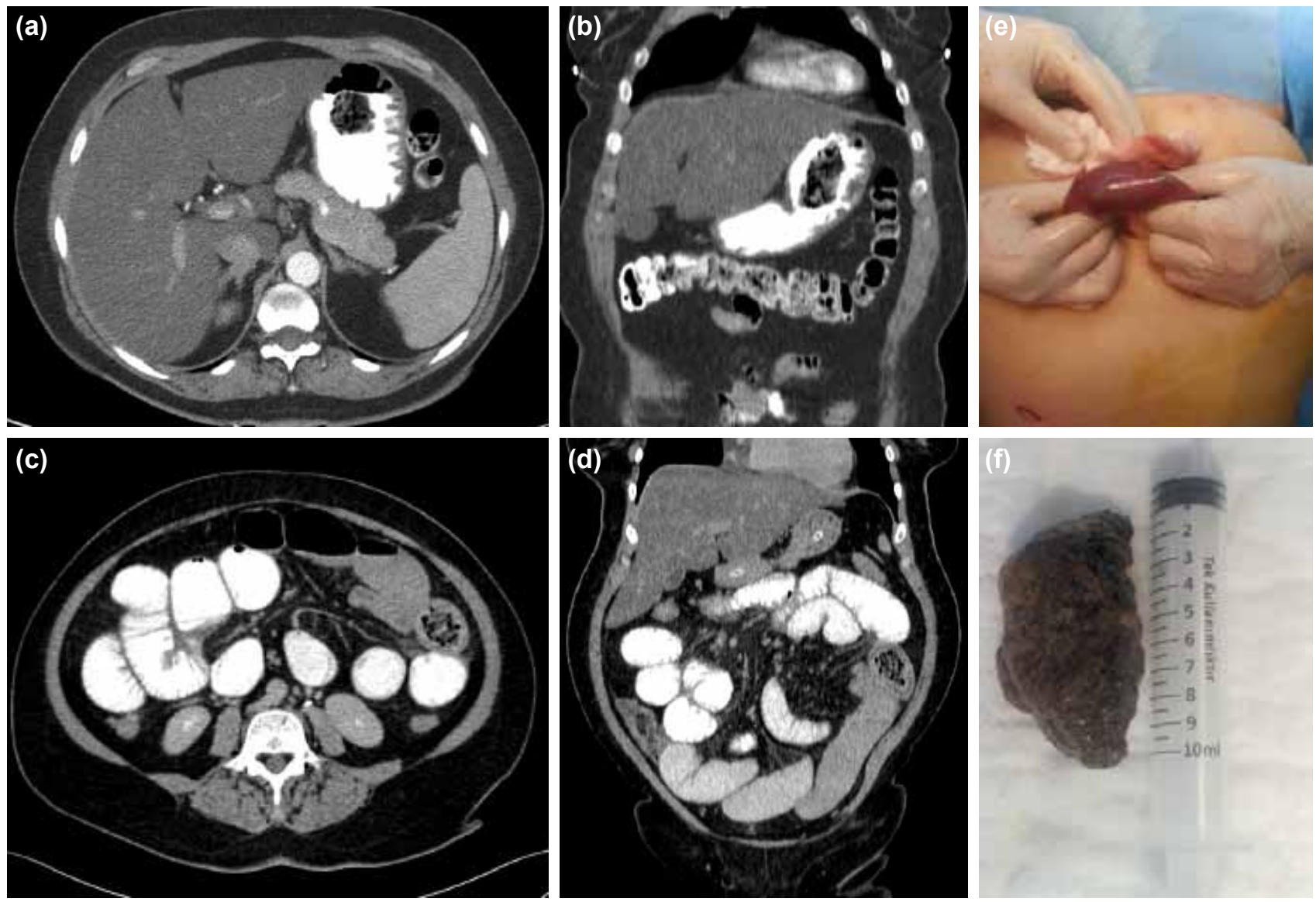

Figure 1. (a, b) Axial and coronal CT scan of abdomen showing intra-gastric well-defined mass with mottled gas pattern typical for bezoars. (c, d) Axial and coronal CT scan of the abdomen showing dilated intestinal loops and intraluminal well-defined mass with mottled gas pattern. (e) Intraoperative appearance of small intestinal obstruction. (f) Macroscopic appearance of diospyrobezoar. 
ischemic ulceration, perforation and gastrointestinal bleeding are reported as complications. ${ }^{[8]}$

\section{Conclusion}

Diospyrobezoars rarely cause intestinal obstruction; however, this possibility must always be considered. If a bezoar is discovered in the gastrointestinal system, treatment (especially non-surgical ones) should be planned immediately since by the journey of the bezoar from the stomach to the intestine, obstruction may develop in a very short time.

\section{Conflict of interest: None declared.}

\section{REFERENCES}

1. Andrus CH, Ponsky JL. Bezoars: classification, pathophysiology, and treatment. Am J Gastroenterol 1988;83:476-8.
2. Erzurumlu K, Malazgirt Z, Bektas A, Dervisoglu A, Polat C, Senyurek G, et al. Gastrointestinal bezoars: a retrospective analysis of 34 cases. World J Gastroenterol 2005;11:1813-7.

3. Altintoprak F, Degirmenci B, Dikicier E, Cakmak G, Kivilcim T, Akbulut $\mathrm{G}$, et al. CT findings of patients with small bowel obstruction due to bezoar: a descriptive study. ScientificWorldJournal 2013;18:298392.

4. Gayà J, Barranco L, Llompart A, Reyes J, Obrador A. Persimmon bezoars: a successful combined therapy. Gastrointest Endosc 2002;55:5813. CrossRef

5. Teng H, Nawawi O, Ng K, Yik Y. Phytobezoar: an unusual cause of intestinal obstruction. Biomed Imaging Interv J 2005;1:e4. CrossRef

6. Ezzat RF, Rashid SA, Rashid AT, Abdullah KM, Ahmed SM. Small intestinal obstruction due to phytobezoar: a case report. J Med Case Rep 2009;3:9312. CrossRef

7. Pujar KA, Pai AS, Hiremath VB. Phytobezoar: a rare cause of small bowel obstruction. J Clin Diagn Res 2013;7:2298-9.

8. de Toledo AP, Rodrigues FH, Rodrigues MR, Sato DT, Nonose R, Nascimento EF, et al. Diospyrobezoar as a cause of small bowel obstruction. Case Rep Gastroenterol 2012;6:596-603. CrossRef

\section{OLGU SUNUMU - ÖZET}

\section{Gastrik bezoarın tomografik yolculuğu}

Dr. Deniz Çebi OIgun, ${ }^{1}$ Dr. Yasemin Kayadibi, ${ }^{1}$ Dr. Osman Şimşek, ${ }^{2}$ Dr. Zekeriya Karaduman ${ }^{2}$

${ }^{1}$ İstanbul Üniversitesi Cerrahpaşa Tıp Fakültesi, Radyoloji Anabilim Dalı, İstanbul;

${ }^{2}$ İstanbul Üniversitesi Cerrahpaşa Tıp Fakültesi, Genel Cerrahi Anabilim Dalı, İstanbul

Fitobezoarlar nadiren intestinal tıkanıklığa yol açarlar. Genelde önceden geçirilmiş mide cerrahisi, diyabet veya ağız-diş problemi gibi predispozan sebepleri bulunan hastalarda saptanırlar. Bu yazıda gastrik bezoarın migrasyonu sebebiyle oluşan nadir bir intestinal tıkanıklık sebebini sunmayı amaçladık.

Anahtar sözcükler: Fitobezoar; intestinal tıkanıklık; migrasyon; Trabzon hurması.

Ulus Travma Acil Cerrahi Derg 20।4;20(5):389-39| doi: 10.5505/tjtes.20।4.59422 